\title{
Elements of Naturalism in McTeague by Frank
} Norris

\section{Anwar Nessir Surur, Senbeta Tadesse Dengela}

Wolkite University, College of Social Science and Humanities, English Department, Ethiopia

\begin{abstract}
Naturalism as a literary theory emerged in the $19^{\text {th }}$ century in reaction to different philosophical,, scientific, and socio economical developments of the time. Particularly Charles Darwin's theory of origin of species and August Comte's philosophy of positivism gave impetus to the inception of naturalism. But literary naturalism was first proposed and formulated by the French Novelist Emile Zola in 1970s. Preparing the whole manifesto of naturalism, Zola universally labeled as the founder of literary naturalism. The theory firmly propagates the scientific observation of life: In literary writing it heavily lies on objective and empirical presentation of human being in its environments. Hence, this paper attempted to examine the basic tenets of naturalism in the novel McTeague by Frank Norris. The study proceeded from illuminating the background and concept of naturalism in the first chapter of the paper to providing the framework that the study to investigate exclusively in chapter two. In this second chapter the concerns of the paper are summarized through illustrating the cannons of naturalism. The last section of the paper, chapter three, is the part to interpret and analyze the literary element of naturalism in regard for the novel McTeague by Frank Norris. Here, the basic elements of naturalism mentioned: determinism, lower class plausible characters, objectivity, immoral contents, language of the actual world and pessimism are illustrated through discussion and substantiation of text extracts. The analysis is performed efficiently in a way to show each elements of naturalism as appeared in the naturalist novel under study: McTeague so as to demonstrate how naturalism is applied in literary writing. Hence, the analysis conducted examining each elements of the theory by substantiating representative extracts from the text.
\end{abstract}

Keywords-McTeague, Frank Norris, naturalism.

\section{BACKGROUND OF THE STUDY}

Naturalism is a concept that has been used in literature, theology, philosophy and art. In theology, naturalism advocated the idea that religious truth may be achieved through the study of natural causes and not through revelation. In philosophy, the theory of naturalism shaped the belief that world phenomena were to be accounted for in terms of natural forces rather than spiritual or metaphysical explanation.

The literary form of naturalism, which is the concern of this paper, began to appear in 1960s, in France, from its predecessor, Realism. According to Emile Zola, the development of literary styles from realism to naturalism started with writers such as Stendhal, Balzac, Flaubert and the Goncourt brothers. These writers laid the foundation for literary Naturalism by incorporating some naturalistic features into their realistic novels. But Naturalism became renowned as distinct literary movement after the French writer and theorist Zola's detailed description and characterization of the theory, formulating its manifesto.
Emile Zola, was the first scholar to coin the term "Naturalism" and universally labeled as the founder of literary Naturalism. The form of this literary movement, hence, got its basic foundation after publication of his novel, "L"Assammoir" in the late 1970s.

In this period Naturalism started in against idealistic way of novel writing, especially romanticism, which present existence and human life away from reality. Naturalism as concept and movement in literature, thus, strongly advocate that literary composition should be based on an objective, empirical presentation of human beings. The scientific methods infiltrated into the literature; the word "writer"could have been substituted easily with the term 'scientist', according to Zola, because both the writer and the scientist can experiment with his material.

Naturalists, contrary to Romanticism, believe that art should be a representation of reality of the outer world and that it should not be based on imagination or on a subjective point of view. Hence, naturalism can be viewed as a more extreme form of realism, extending creative writing to be based on 
scientific facts by encompassing heredity and environment as an absolute determiners of the actions of human being and refusing to accommodate any kind of metaphysical or spiritual perspective. The theory of evolution called "On the Origin of Species by Means of Natural Selection" which published by British scientist Sir Charles Darwin in 1859 considered as direct source of Naturalism from scientific point of view. The effect was that the Theory served as a basis for Emile Zola, who took its most important premise of a man being developed from animal and his behavior according to his deepest instincts and passions being natural for him. This resulted in descriptions of man's life as a continuous struggle between heredity, circumstances and environment of a moment; and from naturalistic point of view people are not far from animals.

Positivistic philosophy which formulated by the French philosopher Auguste Comte in the first half of the nineteenth century served as another source for literary Naturalism. Comte criticized metaphysics for its ungrounded speculations and labeled it as "a relic of theological and mythological period of mankind development." (Mikysková, 8). According to his thoughts the main aim of science is a classification and systematization of cognition based on the method of observation and sensory perception. Science is therefore restricted only to the observable but when systematized and organized it enables predictable situations and phenomena not only in science itself but in society as well. Proponents of positivist thought, so, "wished to exclude from investigation all hypotheses that were not empirically verifiable, and they rejected as "metaphysical" all inquiries that were not ultimately reducible to supposedly scientific terms."(Habib,470). Comte dealt with social organization and was convinced that any society passes through three intellectual stages--interpreting phenomena: 1. theologically, 2. metaphysically, 3. positively (Mikysková, 8). The first stage which corresponds with supernaturalism and the second one the same as observation were not considered in comate's philosophical thought. It is the final one, positivistic stage, with respect to science and its methods based the development of Naturalism. Zola then connected this knowledge with Naturalism in respect of justifying his argument that novel writing to be entirely oriented in to experiment and scientific facts.

\section{STATEMENT OF THE PROBLEM}

Naturalism is a great movement which profoundly influences manifestation and the whole mentality of writers and the society at large. The theory as literary movement solely dominated the form of writing from 1870 to 1940 around the world, and it still continued to affect fictitious writings of all genres of our era. Today naturalistic way of writing in parallel with the newly developed styles of writing; modernism, post-modernism and others; provide an alternative for artistic manifestation. Objective, empirical, determinate nature of the theory in presenting life, make it foremost, and be preferred, to depict historical and scientific facts which have great deal of impact in the society. However, this way of exhibiting the prevailing conditions in Ethiopian literary works is a rare case. Even if globalization significantly joined the whole world together, our nation haven't notably exposed to naturalistic way of writing which appeared in the whole world for the last century. Hence, naturalism is still in its infancy stage in Ethiopia. In fact such restriction in proliferation of naturalism is partially occurred because of the country's limited contact with European super powers. Particularly the existence of the country preserving its independence from colonialism throughout its history contributed for this. This is because, apart from material and institutional factors, colonialism contributed great deal for diffusion of Naturalism from its center, Europe. Hill in his book The Travels of Naturalism and the Challenges of a World Literary History emphasize this fact.

Many of the material and institutional
developments that Chevrel cites as factors in
the spread of naturalism in Europe
contributed to the development of the
transnational intellectual culture of which
naturalism was a part. .. To these factors we
should add the immense prestige of European
cultural products, supported by the political
and economic control that several European
countries exerted over large parts of the
globe. Such prestige garnered great attention
in subordinate regions for the latest cultural
developments in Paris, London, and Berlin,
whose aspirations to ,modernity" frequently
defined the aspirations of others. Naturalism
was both a manifestation and an observation
of such aspirations. (2009:1202)

Indeed, Sibhat G/egzabher tried to incorporate some elements of naturalism in his writings. But his works cannot be considered as purely naturalistic, lack some basic features of Naturalism. His works dominantly portrays mere sexual impulses which human in real world succumb to. Doing so, Sibhat ables to attain some of the naturalistic elements: immorality and actual language in his nobles: Tikusat(Fever), 
Amist Sidist Sebat (Five Six Seven), Letum Aynegaling (Dawn Yet Not). But his works couldn't effectively visualize the prominent features, determinism and pessimism, upon which Naturalism formulated.

More importantly as an assessment of the researcher, there is no any study conducted so far in regard with literary Naturalism. Currently ample of studies are undertaken on different literary theories and other concepts of literature by postgraduate students and other academic scholars. But as my persistent search, I couldn't come across to a single work on the field. Naturalism as literary manifestation seems to lack attention in Ethiopian context. So, this negligence of research on the subject among Ethiopian scholars and writers inspired the researcher to shed light on the field. Accordingly, the study will try to depict important elements of literary Naturalism by studying the novel McTeague by Frank Norris as a point of reference. The researcher picked foreign novel to analyze naturalistic elements because there are no local novels which have been written with full orientation of naturalism; the researcher lacked there local (Ethiopian) novels having basic elements of naturalistic novel writings.

\section{OBJECTIVE OF THE STUDY}

This study is inspired by a prime need to acquaint Naturalistic form of writing in Ethiopian by propagating its conceptual grounds and distinct way of representing human conditions. Having this basic ground the study will be conducted to achieve the following objectives.

- To examine the basic tenets of literary Naturalism and hence halt the prevailing confusion between Naturalism and other literary theories, particularly Realism.

- To offer a general framework for the analysis of literary works written from the Naturalistic point of view.

- To offer approaches of naturalism for those who seek to write naturalistically

- To show the how Naturalistic form of writing represents human beings in relation to the whole surroundings which construct existence.

\section{SIGNIFICANCE OF THE STUDY}

The relevance of undertaking study on prominent literary theory, Naturalism, is crucial to evaluate its extent of application in creative works and come across with the cannons the theory formulated on. Especially, it is indispensible in Ethiopian circumstance where very less attempt has done to advance the theory on the level of research and literary manifestations as well. This study, as the first attempt on the area, hence, will have far reaching benefit in understanding Naturalism as a literary theory and applying it for different genres of creative writing. In Ethiopia writing being stayed heavenly directing by talent rather than grounding it on internationally accepted theories and style; writing is accidental that, dominantly, composers don't acquire any professional knowledge of literature.

Primarily, thus, this study will help individuals who seek to develop their skill on literary Naturalism by serving as source of knowledge. Apart from this the study will motivate others to engage in conducting further studies on the area in a wider sense. Besides its contribution as reference, the thesis will play vital role to drive the attention of scholars and academicians in familiarizing Naturalism. It also May pave the way to Naturalistic form of writing proliferate among Ethiopian writers. It will initiate composers to adapt the theory for literary works on different socio-economic and political aspects of Ethiopian context.

\section{METHODOLOGY}

This thesis is textual analysis and, hence, all investigation is completely based on close reading of the novel on focus and other reference materials related to the theoretical approach of Naturalism. Thus, the research is confined to library-based study which needs only books in text and electronic form to accomplish. To this effect the researcher critically read materials on the area of Naturalism in a wider sense in order to be clear enough about the theory and understand the stand points the selected novel can be analyzed from. The focus of reading, here, was rested on identifying, conceptualizing, and characterizing Naturalism from relevant sources. Thus all reading of further materials profoundly assist to systematize the study. But the final outcome rested on critical reading of the text selected for analysis. In this regard the researcher thoroughly read the novel McTeague in order to identify different naturalistic features and elements appear on it. Then at the end the analysis is carried out descriptively with the help of the information gathered from source materials. Each important elements of Naturalism are explained with substantiating the right quotes from the novel on study.

\section{THEORETICAL FRAMEWORK}

This part attempted to examine theoretical models that can be used for the analysis of elements of naturalism in McTeague.

\subsection{Cardinal Elements of Literary Naturalism}




\subsubsection{Determinism}

Determinism is basically the opposite of the notion of free will. For determinism, the idea that individuals have a direct influence on the course of their lives is supplanted by fate. The dominant idea of determinism is that human beings have no power to change their circumstances; they presented as the victims of unchecked forces. In contrast to ideal freedom of man, naturalism claims that "such an inner core does not really exist because its place is already occupied by elementary forces beyond the individual's control"(Winfried,2010:207).

Naturalists assert two kinds of determiners responsible for crushing free will in attempt of man. The scholars of the doctrine asserted that the fate of human being has been predetermined by interior (hereditary factors) and exterior (environmental factors), and the destiny of humanity is fated to misery in life that he/she can do nothing about it. Paul, further, noted that free will, actions initiated by the self, the personal accomplishment of goals, had been suppressed by the forces of economics, unconscious desires and natural selection( (2004:172). To amplify different dimensions and effects of determinism some detail of heredity and environment forces will follow.

The basic idea in the heredity determinism is that certain anomalies, mental or physical, or a particular behavior are inherited from the older generation. It is the internal force of passion and instinct, Zola termed as "nerves and blood", which engulfs the self-directed thinking and actions of human. Naturalistic scholars usually give more emphasis to hereditary aspects of determinants than environmental. He claims that the elaborate machinery of law and custom developed by civilization is scarcely sufficient to hold in check the self-assertive impulses, the hard-driving force of the ego. (1962 :15). Zola also declares: "I consider that the question of heredity has a great influence in the intellectual and passionate manifestation of man"(ibid.19).

Here, Zola, beyond contextualizing heredity determinism to application in a particular novel, he demonstrates the associative extension of bad internal impulses, primitivism. Primitivism is another underlying feature of naturalism that the species of human being generally treated as uncivilized. Hereditary factors and the consequent surrender of man for them are the sole responsible agents for this effect. From the view of naturalism people are presented as creatures with a hidden inside animal, which rules them and brings them back to their predecessors in species evolution. The author of the school pertain that "people are not far from animals, considered as lower creatures in comparison with a human.
This outcome, when humans are seen as close relatives to animals with all their passions and basic instincts"( mikysková, 2008:18).

An environment is another major determiner which entertains combined forces of economic conditions, social interactions, weather and geography. For Naturalists it was vital to persuade the reader about their truth, which means that environment and the situation are responsible for people's characters and development of their life stories (Zola,1893). The web (http://www.ehow.com) vitalizes the physical environment (weather and geography) as the dominant influencing agent. The primary external conflict in naturalistic literature is between man and nature. Harsh weather conditions, natural disasters, droughts and famine are the primary forces always struggling against man. On the other hand, as hereditary forces, Kamal El Fouadi locates the incapability of human in the face of environmental determiners; man is strived to knuckle down and bear the pressure of social forces. But man's endeavor become fruitless and unable to change what is around him (1989:79).

\subsubsection{Pessimism}

Pessimism is another founding feature of naturalism on which gloomy side of the world is demonstrated sincerely. In naturalistic literatures characters usually fated to harsh treatment or tragic fall at the end of novels and holds. Pessimism as a principle provokes the idea that humans in the real world are surrounded by multifarious misery and melancholy. So, naturalistic works often exposed those sordid subject matters like poverty, racism, sex, prejudice, disease, prostitution, and filth environment. Naturalism by mean is "realism infused with pessimistic determinism"(Pizer :11). Norris believed that the source of such harsh treatment beneath the surface of commonplace is the presence of animalistic traits in all human being which are inherited from evolutionary development.

\subsubsection{Amoral in Content}

Scholars debated for years to theorize the true nature of morality and goodness. They attempted to draft the guiding principle of morality. Most argues for objective morality that humans are born with a conscience to identify basic moral principles. Paul Copan confirms: "We possess an in-built "yuck factor"- basic moral intuitions about the wrongness of torturing babies for fun, of raping, murdering, or abusing children. Copan also listed four principles regarding basic moralities: (1) no inferential or directly apprehended; (2) firm (they must be believed as propositions); 
comprehensible (intuitions are formed in the light of an adequate understanding of their propositional objects); and (4) pre-theoretical (ibid. 144). The theory of naturalism , thus, is generally labeled as immoral. Naturalists often act against the social norms or against the will of individuals under the pressure of circumstances.

\subsubsection{Objectivity}

The writers of the school thus used a version of the scientific method to write their novels; they studied human beings governed by their instincts and passions as well as the ways in which the characters' lives were governed by forces of heredity and environment. Objectivity, here, thus stresses the high level of truth naturalism firmly attains. So the description may serve as future analysis of the case the author is studying at the moment. Naturalists only concern is being fact, and they don't pay attention for the objection or negative feeling which can be develop from the side of society in relation to rough subjects handled by. Thus the naturalistic writers are not attempted merely to write fiction, but envisioned to provide a report on human's real life.

\section{ANALYSIS OF THE STUDY}

In the previous chapters the theoretical base and background of the study have been discussed. In this chapter, as the focal part of the study, significant elements of naturalism explicated so far are presented as they appear in the novel under study. After providing the synopsis of the novel, the elements of naturalism reflected in it are discussed through substantiating representative quotes from the novel.

\subsection{Analyzing Elements of Naturalism in McTeague}

\subsubsection{Determinism}

\subsubsection{Hereditary Determinism and Consequent Human}

\section{Primitivism}

The novel, McTeague, has many ways to scrutinize hereditary determinism. The relationships between the characters in the story are strange that all characters are not free individuals in charge of their own destiny. Rather the characters fated to conditions which were not been planned to be so. Hence, all the characters submitted to the instinctive desire and emotion inherited from older generations. Except Old Grannies and Miss Baker all succumb to the evil instinct rooted in their soul. McTeague overcome by his brutish desire of sex and obsession for money, Trina by extreme greediness, Marcus by jealousy and obsession for money, Zerkow by greediness and jealousy and Maria by her silly nature. Consequently, the characters civilizatory control and inner-directedness suppressed by animalistic desires; because of the hereditary intuitive, the characters commit violent crimes and injustice to their acquaintances.

These temperaments of characters, on the other hand, reveal primitive stage of human development. First, in the first half of the story, it seems that many of the characters come together. For example, Marcus and McTeague become friends, Trina and McTeague get married, Maria and Zerkow get married. However, as the story ends, these evil desires push the characters against their rational will and thus the friendships of the characters break down into violence and death. The story presented characters as harshly determined by their biological inheritance and primitive. Let these features asserted through providing representative quotes from the text. The following extract explicates how sexual desire in the dentist McTeague affects the normal functioning in operating his client, Trina.

Suddenly the animal in the man stirred and woke; the evil instincts that in him were so close to the surface leaped to life, shouting and clamoring. It was a crisis-a crisis that had arisen all in an instant; a crisis for which he was totally unprepared. Blindly, and without knowing why, McTeague fought against it, moved by an unreasoned instinct of resistance. Within him, acertain second self, another better McTeague rose with the brute; both were strong, with the huge crude strength of the man himself... the better self that cries, "Down, down," without knowing why; that grips the monster; that fights to struggle it. ... Suddenly he leaned over and kissed her, grossly, full on the mouth (p.34-37).

In this excerpt the two forces residing in the major character McTeague's self are forwarded vividly. The one is the rational and civilizatory and the other is the emotional and evil instinct which is inherence from the fore-fathers. These two forces wage fighting to suppress each other, but, finally, emotional instinct in McTeague triumph over the rational. Hence, against his profession McTeague forcedly kissed Trina when he was operating her teeth. Here, the hereditary instinct of desire for sex determines the will of the character and he treated to be primitive.

Trina ,too, is depicted as greed to admit any of McTeagues demand for money. Hence, being annoyed by avaricious condition of Trina, at the end, he cruelly kills her and burglarize all her money she possessed from lottery prize and miseries hoarding. 
He came back at her again, his eyes drawn to two fine twinkling points, and his enormous fists, clenched till the knuckles whitened, raised in the air. Then it became abominable [towards the morning Trina died]... The dentist took the lid lifter from the little oil stove, put it underneath the lock-clasp and wrenched it open. Groping beneath a pile of dresses he found the chamois-skin bag, the little brass match-box, and, at the very bottom, carefully thrust into one corner, the canvas sack crammed to the mouth with twenty-dollar gold pieces. He emptied the chamois-skin bag and the matchbox into the pockets of his trousers (p.412-13).

For animalistic wishes McTeague murders his wife and takes the lottery treasure and other money of her she saved by being devoid of, even, from her basic needs. But this hereditary passion for money couldn't bring McTeague to the state of prosperity rather speeds up his fall. Even though he wishes success, evil instincts of hereditary works against him. After killing Trina, when he was attempting to escape sheriffs, he trapped by another misfortune. When McTeague proceeds to Death Valley partially to flee legal arrest and on the other way to accomplish his motive for gold mine, he overwhelmed by the harsh desert and died there. The other major character Trina also conquered by her heredity traits. The dominant hereditary evil in Trina is extreme greediness in which she hasn't any thing valued more than money. Even though Trina wins five thousand dollar, she progresses to become more miser and hoards every penny without any pity to her families and husband. But only one more extract is provided here to reinforce the quote above.

"Well, Trina," he said, "we got that house. I've taken it."

"What do you mean?" she answered, quickly. The dentist told her. "And you signed a paper for the first month's rent?"

"Well, I guess we can stand thirty-five dollars," mumbled the dentist,

"if we've got to." "Thirty-five dollars just thrown out of the window," cried Trina, her teeth clicking, every instinct of her parsimony aroused. "Oh, you the thick-wittedest man that I ever knew. Do you think we're millionaires? ... Suddenly she rose to her feet and slammed the chopping-bowl down upon the table.
"Well, I won't pay a nickel of it," she exclaimed (p.226-27).

The one-room house, in the flat of folk street, where the couple residing, usually is referred by McTeague as "rats" hole". Particularly, after their fortune of the lottery prize, McTeague becomes curious to have house which qualify their present state of wealth. However, despite the fact Trina wins five thousand dollar lottery, she refused McTeague's proposal to change their residence to improved house. She prefers to have more saving than leading relaxed life. The genetic trait Trina inherited from her forefathers and far animal ancestors, pushed her down to extreme avaricious state. Instinct of greed which deep-rooted in her so determines her fate that McTeague, troubled by her strict control of money, terribly murders and take away the whole treasure she hoards for years.

Similarly, the other character, Zerkow, also afflicted by inherited evil of greed. After the poor junk seller, Maria, told him about wonderful service of gold dishes her folks used to possess, he provoked to make this property his own. The greed embodied in him forced to involve in guilty acts for the sake of holding the gold told by Maria. Even the marriage between him and Maria engaged purely to realize the material need on the side of Zerkow: "Now he's going to marry her just so's he can hear that story every day, every hour. But when Zerkow noticed that his pseudo-wife is not consented to tell further about her mythical gold treasure, he begins to abuse Maria. On the other hand Maria's refusal to tell about the gold plates she was insistent previously is not intentional. After she suffered from dementia all her memories are knocked out of her mind. But Zerkow is not in a good state to understand agony. Triggered by his evil instinct of greed, the hideous happened at the end, he brutally killed Maria. Zerkow is also exceptionalness in this regard that tasted the same fate as his wife; he gets died of unknown cause in the bay near Black Point. The basic argument in the devastation of these individuals in such a way is that both become the victims of irresistible animalistic desires inherent in their inner self. Zerkow wipe out of his evil intuition of greed whereas Maria of foolish nature that recklessly speaks whomever about her families fortune of old.

You fool! Don't you dare try an' cheat ME, or I'll DO for you. You know about the gold plate, and you know where it is." Suddenly he pitched his voice at the prolonged rasping shout with which he made his street cry. He rose to his feet, his long, prehensile fingers curled into fists. He was menacing, terrible in 
his rage. He leaned over Maria, his fists in

her face.(p.127)

The discussion above thus shows how the fate surpasses the will of characters. All the notable characters in the novel, less or more, have their individual goal to achieve in their life. But all drastically overcome by their instinctual desires what Zola calls their "nerve and blood". The characters couldn't survive because couldn't satisfactory resist the lower self in them. For instance when Trina wins lottery and after their marriage McTeague aspires better life in future. However, the genetic heritage brings him to the direction opposite to his primary wishes and devastates at the end, the fate come ahead of will. This asserts the reality that the misfortunes face the majority of the people in the real world are rooted from hereditary limitations prevail in them.

\subsubsection{Environmental Determinism}

The social and geographical environment is another determining agent of the actions and progress of the characters in McTeague. The human and natural environment they all lived in does not allow them to find a better life and above all causes their complete failure. At the end of the story we find that every one dreadfully fallen under joint forces of sever environment and instinct. The Prevailing social conditions in McTeague, the society of San Francisco in general and the social interaction between the residents of the tenement at Folk Street, profoundly influence all characters' lives. This aspect of determinism is more evident in major characters McTeague and Marcus. McTeague is pseudo-professional of dentist who opened 'Dental Parlor' at Polk Street of San Francisco. He acquired the skill of operating teeth through practice without attending formal education of the profession. This profession of him in progress brings in contact with different clients and the society of the town. Particularly, McTeague relation with Marcus is significant to examine the extent of social environment in determining the life of characters.

Marcus Schouler was the dentist's one intimate friend. The acquaintance had begun at the car conductors' coffee-joint, where the two occupied the same table and met at every meal. Then they made the discovery that they both lived in the same flat, Marcus occupying a room on the floor above McTeague. On different occasions McTeague had treated Marcus for an ulcerated tooth and had refused to accept payment. Soon it came to be an understood thing between them.(p.12)
The social acquaintance in this segment of the story foreshadows the cause for gradual failure and at last complete devastate of the three characters. In other words this first contact between the characters implies that if the social condition didn't bring the two characters together, the consequent tragedy afflicts the characters may not occur. This first interaction is thus crucial to understand the whole misfortunes befall on the major characters of the novel, McTeague, Marcus and Trina.

In light of this, although the intimacy between McTeague and Marcus is fascinating at the beginning, it couldn't last for long. After Trina, wife of McTeague and cousin of Marcus, win the prize of five thousand dollar lottery, the social bond between the two characters strained and they come in to hostile rivals. This critical event agitated Marcus to take unusual measures. When they meet at Frenna's of Folk Street attempted to kill his former intimate friend: "Marcus had made a quick, peculiar motion, swinging his arm upward with a wide and sweeping gesture; his jack-knife lay open in his palm; it shot forward as he flung it, glinted sharply by McTeague's head, and struck quivering into the wall behind."(p.160). McTeague narrowly escaped from this danger, but the terrible fighting leads their relation more worsening. Marcus continued to endeavor in his at most effort to drop his newly developed foe, McTeague. At the end, so, informing Mcteague's lack of formal education of dentistry the profession requires to the municipality, Marcus succeeded in outlawing the dental practice by the city administration. This banning of dentistry plays central role to determine the fate of the character McTeague in particular and the whole progress of the story at large. The prohibition throws McTeague into joblessness and agony. From this time on the whole life of the dentist come in to disturbance. Then the intuitive desire sponsored by this bad social environment, forces McTeague to murder his wife and leads him to undertake the hideous travel to southern California. More than social conditions, geographical environment seen as the most binding force to determine the characters destiny in McTeague. Social environment has indirect attachment with final down fall of Mcteague and Marcus, but geographical environment directly intervene to quit the survival of these characters for all. When McTeague is crossing Death Valley of California to escape legal arrest, he captured by harsh climate of the desert.

The sun rose higher; hour by hour, as the dentist tramped steadily on, the heat increased. The baked dry sand crackled into innumerable tiny flakes under his feet. ... At 
eleven the earth was like the surface of a furnace; the air, as McTeague breathed it in, was hot to his lips and the roof of his mouth. The sun was a disk of molten brass swimming in the burnt-out blue of the sky. McTeague stripped off his woolen shirt, and even unbuttoned his flannel undershirt, tying a handkerchief loosely about his neck.(p.460)

Here, the severity of the climate presented in heightened imagery. When McTeague is forwarding to Mexico through Death Valley to be evaded from the legal order, he thwarted by the extreme hot in the desert. From the description it can be conceived the extent the climate threatens the life of the character. McTeague strives hard to knuckle down this hardship, but he couldn't resist and finally comes under unforgivable grip of physical environment.

\subsubsection{Focus on Lower Class Plausible Characters}

Employing lower plausible characters is on basic element of naturalistic novel writing. McTeague is typical naturalist novel in drawing downtrodden and credible characters. The novel reveals the real life of ordinary people living in Polk Street of San Francisco. It depicts the physique, actions and behavior of characters convincingly of real world. The surrounding the characters located is also representative of the majority people of that times society. So the characters are presented life-like to the extent that the audiences seem to view them in outside world. The story particularly situated at peoples residing in the same flat at Polk Street of San Francisco. These characters' lower status can be expressed from their socio-economic ground they thrown into. As revealed from the story most of these characters illiterate and are engaged in inferior jobs as their livelihood and consequently wrenched to worsening living standard.

The first indication of the characters unsophisticated life status in McTeague is their being unfortunate to possess home of their own by which all the significant characters dwell in the rented house of the same flat. The protagonist McTeague formerly was carboy at Big Dipper mine. But trough time, even though he didn't obtain professional education, McTeague opened dental clinic and could leap to the title of "Doctor". Notwithstanding his pseudoprofessional, so, for some period of time, McTeague practices dentistry as his means of income. However, his life is still unimproved. The underprivileged condition of him when working dentistry mentioned in the story: "When he opened his Dental Parlors, he felt that his life was a success that could hope for nothing better. In spite of the name, there was but one room. It was a corner room on the second floor over the branch post-office, and faced the street. McTeague made it do for a bedroom as well, sleeping on the big bedlounge against the wall opposite the window"(p.6). This excerpt explains poor status of McTeague who lives and works in a single room in the flat. Above all, McTegue twists to more deteriorating condition in his latter life. After he has been prohibited to perform dentistry because of his illiteracy, he becomes jobless and involve in violent crimes.

More importantly, Maria Macap is the poorest of all characters. She works as care giver of the flat and collector of junks that she gathers cracked and old utensils from the homes of the flat's resident. Then she sales junks to Zerkow for a very minimum amount of money in order to lead her extra-ordinary life. "Once every two months Maria Macapa set the entire flat in commotion. ....She was collecting junks, bits of iron, stone jugs, glass bottles, old sacks, and cast-off garments... She sold the junk to Zerkow, the rags-bottlessacks man" (p.39).

The life of other characters, Marcus, Old Grannis ,Miss Baker and Sieppes is not better. Marcus serve as assistant of Old Grannis in dog hospital ,Miss Baker is the retired jobless lady, the families of Trina ,Sippes incur business failure. Although Trina achieves good deal of money from the lottery prizes, she couldn't lead prosperous life rather become more miserable because of her avaricious nature. Apart from the characters who directly participating in the actions of the story, Norris also point out the whole degraded society of the city. He portrays the reality of life in the morning hour when the people of the city are rushing to their daily activities.

The laborers went trudging past in a straggling file - plumbers' apprentices, their pockets stuffed with sections of lead pipe, tweezers, and pliers; carpenters, carrying nothing but their little pasteboard lunch baskets painted to imitate leather; gangs of street workers, their overalls soiled with yellow clay, their picks and longhandled shovels over their shoulders; plasterers, spotted with lime from head to foot (p.8).

\subsubsection{Objective Presentation}

McTeague is a genuine depiction of varied circumstances of San Francisco and the whole California in the end of 19th century. The same way Norris referred the novel as "A Story of San Francisco" to signify the novel as reportage of different circumstances of the city. McTeague depicts the real socio-economic, cultural and psychological manifestation of the then society of San Francisco. It also authentically informs the geographical and social features of the land from San Francisco to Death Valley of California. 
The objectivity in the novel attains to the extent of presenting occurrences and situations in conformity to truths of scientific findings. In this regard the novel is not written for mere entertainment rather to provide documentary facts about the region and its people. Like other non-literary subjects of social science, McTeague can be served as source of knowledge.

Norris, in the book, retained the highest truth in his description of social and geographical environment the story set. Along with narrating events the characters encounter, the writer reports the real sub-localities of the metropolitan, San Francisco. Apart from Folk Street, the focal point of the story, constitutive areas, like Cliff House, the Park, Presidio Reservation, Union Street, Old Fort, Golden Gate are portrayed as the authentic districts of the metropolitan. Such firm perseverance of objectivity thus enables to depict the distinctive true features positioned in the city. Besides, the legitimate representation of socio-physical environment in McTeague, along with chronological line of the story, extends further to southern California. The localities of California: Iowa Hill, Big Dipper mine, Emigrant Gap ,Reno, Keeler, Panamint and Death valley accurately described.

"Well, it's mostly cattle down here in the Panamint, but since the strike over at Gold Gulch some of the boys have gone prospecting. There's gold in them damn Panamint Mountains. If you can find a good long 'contact' of country rocks you ain't far from it. There's a couple of fellars from Redlands has located four claims around Gold Gulch"(p.435).

This passage directly refers the discovery of gold in California in 1849 and the consequent influx of emigrants from different states of USA and other parts of the world. The story demonstrates the factual condition happened in the half of nineteenth century. To assert the degree of objectivity maintained in the novel, let compare it what non literary sources stated about circumstance. As a result a vast number of people came when the news of gold had spread. Although a lot of people had come to seek their fortune in gold, few people became rich, and those who became rich became very rich. The novel in this regard marks the time when crucial socio-economic changes happen in the history of San Francisco.

Also McTeague and Cribbens in their search for gold presents the scientific description about associative geological signs where gold may exists. "Cribbens had evidently read a good many books upon the subject, and had already prospected in something of a scientific manner. "Shucks!" he exclaimed. "Gi me a long distinct contact between sedimentary and igneous rocks, an' I'll sink a shaft without ever SEEING 'color'" (p.436). The statement confirms the scientific fact about the geological location of gold, in a place where sedimentary and igneous rocks meet. These two instances show how the novel attains objectivity in its content through depending on scientifically asserted proofs.

In line with this the novel also exposes different Psychological facts of human nature. Important of all to be noted is the account provided about the psychology of feminine sex in their relation with male counterpart. The young lady Trina in the novel refuses the love proposal by McTeague for a long. But one day, McTeague derived by harsh inner instinct, conquers Trina and able to kiss her without her consent:

But he had only to take her in his arms, to crush down her struggle with his enormous strength, to subdue her, conquer her by sheer brute force, and she gave up in an instant. But why - why had she done so? Why did she feel the desire, the necessity of being conquered by a superior strength? Why did it please her? "(p.98).

In this example it is evident that the girl who lacks a little of interest to the boy ,so far, find to be pleasant when she subjugated by superior male. In a sudden event, in response to stronger force she has been faced, her inner psychology adjusted so as to bring her from hate to love. This is asserted psychological fact of women that they are fond of physically or economically mightier man to be their lover: "According to the women ...they want to know their partner will be able to protect them physically in times of danger or trouble. That's not to say women are weak it's a security thing and knowing that their partner is capable or willing to protect them at all costs gives women a little more peace of mind. (http://www.stevenaitchison. qualities-women-want-intheir$\mathrm{men} /$ )

Furthermore, the novel truly exhibits the socio-cultural and political manifestations of the society of San Francisco. The then rituals in wedding ceremony, social gatherings, the cultural habit of eating and food items, legal considerations and the role of women in a family of San Francisco are recreated in the novel. The text, followed, about Trina"es wedding reveals the customary practice of presentation and items to be gifted before marriage of couples: The presents had been set out on the extension table in the sitting-room Trina's parents had given her an ice-water set, and a carving knife and fork with elk-horn handles. (p.177) 
Accordingly the observance of presentation for expectant couples was firm cultural practice among the people of SanFrancisco. As suggested, here, it is cultural duty that the relatives should offer gifts for the girl to marry. But their presentation varies according to the economic power the relatives positioned. This is done with intention to equip the couple materially before they engrossed in to the new orderly life departing from the family.

\subsubsection{Language of the Actual World}

The purpose of this section is to try to assess the extent to which Norris managed to enhance the naturalistic position of the novel in aspect of language. In light of language, naturalism expressed through colloquialism in vocabulary and grammar, irregularity in the flow of speech and thought, and unnecessary repetition. These features provide quality of actuality to the novels of naturalism; make the dialogue in the novel look like actual conversation spoken in ordinary life. In McTeague colloquialism and irregularity is not pervasively employed through the story. Yet some characters constantly presented in their life-like informal language. Although it is not feasible to react to all actual commonplace language uses in the novel, it is attempted to depict naturalistic language through providing sample representative extracts from the novel.

In the story no-standardized English, relatively, employed significantly to create the effect of naturalism. Let look the exchange performed between Marcus and Mrs.sieppe when they are dealing about the planned weekend picnic to Schuetzen Park. Because the utterance is so informal, word for word transcription of the first turn of the dialogue is provided in bracket in order to minimize the confusion can be created.

"We go to der park, Schuetzen Park, mit alle
dem childern, a little eggs-kursion, eh not
soh? We breathe der freshes air, a
celubration, a pignic bei der seashore on. Ach,
dot wull be soh gay, ah?" (we go to the park,
Schuetzen Park with all the children a little
eggs-kursion, ah not so? We breath the fresh
air, a celebration, a picnic by the seashore on
oh that will be so gay) (p.73)

Here it can be perceived that how the communicators used non-standardized English to the extent of puzzling the reader to understand its content. The vocabulary, pronunciation, and grammar in their utterance far deviates from formal English. However, this speech is ordinary for the people familiarized to such version of the language and consequently gets the interaction into life-like nature. The speech-exchange between the characters is natural that recreated similarly as occurring in the conversation of daily life.

Maria, as well, characterized as speaking colloquial English. Let consider one instance of her speech at occasion demanding of junks to Old Grannis: ",What you alus sewing up them books for, Mister Grannis?" asked Maria, as she began rummaging about in Old Grannis's closet shelves. "There's just hundreds of 'em in here on yer shelves; they ain't no good to you". Though characters in McTeague are not thoroughly left to speak disordered language, at different circumstances they freed to speak their thought irrespective of the need to focus to the topic at hand. To justify this point let substantiate the discussion held between Trina and McTeague when they are undertaking picnic to Schuetzen Park:

"That's so," ..."not a single cloud. Oh, yes;
there is one, just over Telegraph Hill."
"That's smoke." "No, it's a cloud. Smoke isn't
white that way." "'Tis a cloud."
"I knew I was right. I never say a thing unless
I'm pretty sure."
"It looks like a dog's head."
"Don't it? Isn't Marcus fond of dogs? He got a
new dog last week—a setter." (p.80)

In this dialogue the two interlocutors illogically jumped to different topics missing the first point the speech commenced. Within such brief dialogue the communicators deal about two topics, the weather of the day and Marcus's dogs. This shows how the speakers are natural in there interlocution that the dialogue corresponds to real world conversation. People in actual life usually begin talk from certain subject and round to different areas to end their speech with a topic nothing to do with the first point of departure.

\subsubsection{Immoral Contents}

As dealt in the previous chapter the one characteristic feature of naturalistic novelists is their indifferent position for moral norms of the society. The novel McTeague, even though is not persistently amoral, its general manifestation reveals the evil side of man's nature. Although the novel is not more amoral on the level of vocabulary, the actions the characters committed against each other confirms the level of cruelty human beings spirited in nature. Most characters, in the novel, blindly derived by their bad instincts, reacted very brutally to every fault of each other's. Hence, from the content of the narration it can be inferred that Norris in McTeague does not retain the basic moral faculty of man in 
the traditional attitudes said to be oriented. To demonstrate these feature in the novel some instances considered below:

"Mamma wants us to send her fifty dollars. She says they're hard up."

"Well," said the dentist, after a moment, "well, I guess we can send it, can't we?" "Oh, that's easy to say," complained Trina, her little chin in the air, her small pale lips pursed. "I wonder if mamma thinks we're millionaires?"....

"Hoh!" exclaimed McTeague. "Hoh! I guess you got nearer a hundred AN' fifty. That's what I guess YOU got." "I've NOT, I've NOT,"... I manage all right. No, no, I can't possibly afford to send her fifty." $(p .277)$

From the view of deep rooted norm mistreating and disobedience to mother of own considered as extreme wickedness in any society. In light of this in the passage Trina portrayed as severely mean that she refused to help her mother who is in acute state of seeking money. Even if she managed to hoard more than five thousand dollar, Trina doesn't pay least pity to the mother raised her to that status. Because of her obsession for material world, Trina, thus, couldn"t maintain the norm of morality believed to be retained in the society. She also usually mistreats her husband in relation with money. Especially, after McTeague lost his job she sale all personal possessions, emptied his pocket snatching all the money from him and mercilessly pushes him out of home to search job in a harsher climate: "She let him walk the streets in the cold and in the rain. "Miser," he growled behind his mustache. "Miser, nasty little old miser.

\section{2.6. Pessimism}

This topic exhibits the general orientation of naturalism that relates to all other tenet of the theory emphasized above. Pessimism to human's nature and practice is the general motive naturalism founded. It fundamentally demonstrates negative side of life. Similarly, McTeague adhering to naturalism offers a very pessimistic view of humans and society. The whole tone of the novel seems frustrating in which people strive to help only themselves. The novel relies on the depressing lower class life that the main characters placed in filthy environment. More importantly, Norris treats the characters as primitive that dwindled from misery to failure or tragic death. Generally, the negative instinctive subjects of avariciousness, obsession for money and sexual urge as factor for all the misfortunes overwhelmed the characters framed the whole story of the novel. Zerkow's killing of Maria and his death of undefined cause, McTeague Murdering of Trina, and McTeague's death of dehydration highlight the sensational melodramatic end of the central characters. Here, I am not managed to look these all tragic falls of characters.

The next day came a fresh sensation. Polk
Street read of it in the morning papers.
Towards midnight on the day of the murder
Zerkow's body had been found floating in the
bay near Black Point. No one knew whether he
had drowned himself or fallen from one of the
wharves (p.169.)

After Zerkow killed his wife, Maria, escaped from his home. But he couldn't away from the fate of death. He find died of unknown cause in a bay of San Francisco. Whether he commits suicide or killed by other external agent, the central thing is his tragic fall which is pessimism.

\section{CONCLUSION}

This thesis has investigated the theory of naturalism and its practice to literature. It explored the basic tenets and characteristics which underlie naturalism. The project reviewed the basic doctrine of naturalism as it applied in the novel McTeague by Frank Norris. The elements which characterize naturalism: Determinism (hereditary and environmental), lower class plausible character use, commonplace actual language use, objectivity, immoral content, pessimism are examined.

The most underlying elements of naturalism are closely analyzed in reference with the novel under study which is McTeague. Thus, one of the defining element determinism is the pervasive feature of the novel McTeague is depicted vividly in the analysis. The novel exactly conforms to the naturalist's notion of determinism. In this regard, all the major characters of the novel fated to drastic fall-death because of either hereditary animistic behaviors or succumbing environmental limits. Their wills and desires are thwarted by coercive forces of social forces, geographical milieu or inherent institutions.

Complying with objective representation of naturalist ideal, McTeague firmly attains the real situation of the geographical environment the story set and the scientific reality of human and nature. The writer can be compared with a reporter of truly founding conditions that the cultural, social, scientific and geographic facts around California which the story set to. In relation with objectivity, the writer also employed the realistic plausible characters to carry the tenets of naturalism. This achieved by revealing credible 
dimension of both the physical and psychological aspects of characters in the fiction. In the McTeague all the characters employed are downtrodden ones. They are lower characters as all are managed to live in the same rented flat on the filthy side of San Francisco.

Linguistically, also, the novel written to reveal the life-like natural language. The language features of colloquialism, slang, repetition, and irregularity of speech have been explained with the intention to be used as tools for the examination of the degree of similarity between the material provided in the language of the novel and naturally occurring conversation.

\section{REFERENCES}

[1] Abrams, M.H (1999). A glossary of Literary Terms. Boston: Heinle \& Heinle:.

[2] Augustine, Keith (2001).A Defense of Naturalism. Retrieved $\begin{array}{llll}\text { March } & 20 & \text { 2013 }\end{array}$ http://www.infidels.org/library/modern/keith_augustine/thesis html.

[3] Copan,Paul. God, Naturalism, and the Foundations of Morality. Retrieved March 2013 (http://www.paulcopan/God-Naturalism-morality)

[4] Binford ,Paul (2004). American Literary Naturalism: A Passage to Modernity. Retrieved March 20,2013 from www.ic.nanzan-u-ac-jp/tanda.kiyou/paul\%Binford.

[5] Dennes,William(1960).Some Dilemmas of Naturalism. Colombia University Pres.New York.

[6] El Fouadi, Kamal (1989). The scope of naturalism in British working-class Drama, with Particular Reference to Joe Corrie, D.H. Lawrence and Sean O'Casey.

[7] Fluck, Winfried (2010).Romance with America. Universtats Verlag: Heidelbeg.

[8] Forrest, Barbara (2000).Methodological Naturalism and Philosophical Naturalism: Clarifying the Connection $\begin{array}{llll}\text {.Retrieved } & \text { April } & 3,2013 & \text { from }\end{array}$ http://www.infidels.org/library/modern/barbara forrest/naturalism. html.

[9] Habib, M.A.R (2005). Modern Literary Criticism and Theory: A History. Blackwell Publishing Ltd : Oxford.

[10] Hardwick, Charley (1996) .Events of Grace: Naturalism, Existentialism, and Theology Cambridge university press: New York.

[11] Hill ,Christopher (2009).The Travels of Naturalism and the Challenges of a World Literary History. Blackwell Publishing Ltd:Oxford.

[12] Macarthur, David (2004).Naturalism and Skepticism. Harvard University: Cambridge.

[13] Mikysková, Radka(2008).Two Faces of Naturalism. University of Pardubice.
[14] Noble, Donald (2011). John Steinbeck: $\underline{\text { Critical }}$ insights. Salem press.USA

[15] Otto, Rudolf (1907). Naturalism and Religion. Williams \& Norgate Ltd.: London.

[16] Panesar ,Gurdip() Steinbeck, Norris, and Literary Naturalism

[17] Pizer, Donald (1967). Realism and Naturalism in Nineteenth Century American Literature. Southern Illinois University Press: London.

[18] Rossetti ,Gina (2006). Imagining the Primitive in Naturalist and Modernist Literature. University of Missouri Press:Columbia and London

[19] Saministrado, Maria. Naturalism and Crane's Maggie: Metaphor and Paradox. Retrieved March3, 2013 http:// www.newcastle.edu.eu

[20] Schneider, Robert (1962). Frank Norris : The Naturalist as Victorian . Retrieved March 3, 2013 from http://www. $\underline{\text { https.11 }}$

journals.ku.edu/indexphp/amestud/articlinfidels.org/library/ modern/ barbara

[21] Zola, Emile (1893). Experimental Novel. Haskell:New York.

[22] Differences in Naturalism \& Realism in Literature. Retrieved March 3 from http://www.ehow.com/info_8425576. differences-naturalism-realism-literature.html

[23] Naturalistic Characteristics of Literature. Retrived February 252013 from http://www.ehow.com/ifo-10025278-differenttypes-kinds-literature.html

[24] Naturalism and Realism. Retrieved March 3 from http://whatis.thedifferencebetween. com/compare/ naturalismand-realism/

[25] Religious naturalism. Retrieved April 10,2013 from from Wikipedia, the free encyclopedia. http://en.wikipedia.org/wiki/Religious_naturalism

[26] The Need for Naturalism in a Scientific.(2010). Retrieved April 10,2013 from http://www. centerforinquiry.net/blogs/entry/the_need_for_naturalism_in_ a_scientific_age/

[27] http://amsaw.org/amsaw-ithappenedinhistory-040204-zola

[28] (http://mcteague5.blogspot.com/2004/12/mcteague-plotsummary.html)

[29] (http://www.alz.org/ dementia/types-of-dementia.asp)

[30] (http://www.stevenaitchison. qualities-women-want-in-their$\mathrm{men} /$ ) 